\title{
PATHOGENICITY OF Fusarium graminearum ON CREOLE BEANS: GERMINATION, VIGOR AND SEEDLING DAMAGE
}

\author{
Luan Junior Divensi ${ }^{1}$, Daiani Brandler ${ }^{2}$, Jhonatan Paulo Barro ${ }^{3}$, Lucas Antonio Stempkowski ${ }^{3}$, \\ Paola Mendes Milanesi ${ }^{4}$
}

\begin{abstract}
${ }^{1}$ Universidade Federal da Fronteira Sul - Campus Erechim, RS. Bachelor in Agronomy. E-mail: luandivensi@gmail.com

${ }^{2}$ Universidade Tecnológica Federal do Paraná - Campus Pato Branco, PR. Doctorate Student in Agronomy. E-mail: daianibrandler@hotmail.com

${ }^{3}$ Universidade Federal de Viçosa. Doctorate Student in Plant Pathology. E-mail: jhonatan.barro@ufv.br; lucas_stempkowski@hotmail.com

${ }^{4}$ Universidade Federal da Fronteira Sul - Campus Erechim, RS. Plant Pathology Professor. E-mail: paola.milanesi@uffs.edu.br
\end{abstract}

\section{ABSTRACT}

The objective of this study was to evaluate the pathogenicity of Fusarium graminearum on creole bean seeds, quantify the incidence of root lesions and damping off in seedlings, and evaluate the reduction of germination and seed vigor. Two varieties of creole beans, 'Cavalo' and 'Chumbinho', were collected from a family property located in the municipality of Severiano de Almeida, state of Rio Grande do Sul, Brazil. The treatments evaluated were: seeds not inoculated (T1) and inoculated (T2) with $F$. graminearum macroconidia suspension at a concentration of 8.0 $\mathrm{x} 10^{5}$ macroconidia $\mathrm{mL}^{-1}$, and the appearance of lesions and influence on vigor and germination were observed. The variety 'Cavalo' proved to be more susceptible to $F$. graminearum, expressing vigor reduction, incidence of root lesions and damping off. The variety 'Chumbinho' expressed no vigor reduction, although it has occurred reduced incidence of damping off. Regarding root lesions, the 'Chumbinho' variety compares to the variety 'Cavalo'.

Keywords: Damping off, lesions, macroconidia, Phaseolus vulgaris L., severity 
PATOGENICIDADE DE Fusarium graminearum A FEIJÃO CRIOULO: GERMINAÇÃO, VIGOR E DANO EM PLÂNTULAS

\section{RESUMO}

O objetivo deste trabalho foi avaliar a patogenicidade de Fusarium graminearum em sementes de feijão crioulo, quantificar a incidência de lesões radiculares e o tombamento em plântulas e avaliar a redução da germinação e do vigor das sementes. Duas variedades de feijão crioulo, 'Cavalo' e 'Chumbinho' foram coletadas em uma propriedade familiar localizada no município de Severiano de Almeida, no Rio Grande do Sul, Brasil. Os tratamentos avaliados foram: sementes não inoculadas (T1) e inoculadas (T2) com suspensão de macroconídios de $F$. graminearum na concentração de $8,0 \times 10^{5}$ macroconídios $\mathrm{mL}^{-1}$, observando-se o aparecimento de lesões e a influência no vigor e germinação. A variedade 'Cavalo' mostrou-se mais suscetível $a F$. graminearum, expressando redução de vigor, incidência de lesões radiculares e tombamento. A variedade 'Chumbinho' não expressou redução de vigor, embora tenha ocorrido redução na incidência de tombamento. Com relação às lesões radiculares, a variedade 'Chumbinho' se compara à variedade 'Cavalo'.

Palavras-Chave: Damping off, lesões, macroconídios, Phaseolus vulgaris L., severidade

\section{INTRODUCTION}

Fusarium graminearum Schwabe (Teleom. Gibberella zeae (Schw.)), is the causal agent of Fusarium head blight (FHB) in winter cereals. This disease is considered one of the main diseases in the cereal producing regions of southern Brazil, and is influenced by climatic conditions, cultural practices and susceptibility of cultivars (CALORI-DOMINGUES et al., 2007).

The succession wheat-soybean, wheat-bean or wheat-corn crops are the main economic alternative for production systems in the South region of Brazil. However, succession of crops may exert a selection pressure on $F$. graminearum, pathogenic to previously non-host cultures (ELLIS et al., 2011), and has been reported as pathogenic in other non-cereal hosts, such as beans (BILGI et al., 2011) and soybean (ELLIS et al., 2011).

Because $F$. graminearum survives on cultural residues, the initial inoculum is maintained, which may affect seed germination of the next crops, such as non-cereals, predisposing them to 
infection by the pathogen (BRODERS et al., 2007). In bean, $F$. graminearum can affect the development of young tissues, causing damping off, compromising the population of plants in the crop and, consequently, resulting in lower productivity (BILGI et al., 2011; REIS et al., 2014).

However, the parasitism of $F$. graminearum on creole bean seeds and seedlings is still unknown, considering that these varieties are better adapted to the culture conditions present in family agriculture (DIDONET, 2013) and because they have a broad genetic base and greater resistance to diseases (TSUTSUMI et al., 2012).

Thus, the objective of this work was to verify the pathogenicity of $F$. graminearum on creole bean seeds, quantifying the incidence of root lesions and damping off in seedlings and to evaluate the reduction of germination and vigor of the seeds, with inoculation of the pathogen.

\section{MATERIAL AND METHODS}

The experiment was conducted at the Laboratory of Plant Pathology of the Universidade Federal da Fronteira Sul, Campus Erechim - state of Rio Grande do Sul, Brazil, in a 2 x 2 factorial scheme (creole bean varieties $x$ pathogen inoculation), in a completely randomized design and, all the tests were conducted in duplicate. Seeds of two creole bean varieties, called 'Cavalo' and 'Chumbinho' (cycle of 55 and 70 days, group 'carioca' and 'black', respectively), from the 2014/2015 harvest were collected from a family property located in the municipality of Severiano de Almeida, state of Rio Grande do Sul, Brazil. The evaluated treatments were: seeds without inoculation of Fusarium graminearum (T1 - control) and with inoculation of F. graminearum (T2 $-F g$ ).

Using wheat seeds cv. 'Mirante', with symptoms of Fusarium head blight, the seeds were submitted to a superficial disinfestation with ethanol 70\% (30 s), sodium hypochlorite 1\% (30 s), and three successive washes with distilled and sterilized water (30 s). Afterwards, they were seeded in Petri plates containing 15 mL of Potato-Dextrose-Agar (PDA, HIMEDIA ${ }^{\mathrm{TM}}$ ) supplemented with $200 \mathrm{mg} \mathrm{L}^{-1}$ of streptomycin sulphate (NELSON et al., 1983).

After seven days of incubation, colonies with similar characteristics to $F$. graminearum (LESLIE \& SUMMERELL, 2006) were transferred to Petri plates containing agar-water medium (AW), to obtain a monosporic culture (NELSON et al., 1983) and subsequent cultivation in PDA medium (for color observation and colony measurement) and Carnation Leaf Agar medium (CLA) for better characterization of fungal structures. The material was incubated at $25 \pm 2{ }^{\circ} \mathrm{C}$ and 
photoperiod of $12 \mathrm{~h}$, during 10-14 days, when the microstructures of the fungus were observed in a stereoscopic and optical microscope, and the species was identified according to classification keys (LESLIE \& SUMMERELL, 2006).

To confirm the morphological identification of the Fusarium graminearum isolate used in this work, the rDNA of the B-tubulin region was performed, with the oligonucleotides Bt2a (5'GGTAACCAAATCGGTGCTGCTTTC-3') and Bt2b (5' ACCCTCAGTGTAGTGACCCTTGGC -3'), according to Glass \& Donaldson (1995). The RPB2 region was also sequenced and, for this, the oligonucleotides 5F2 (5' GGGGWGAYCAGAAGAAGGC) and 7cR (5' - CCCATRGCTTGYTTRCCCAT), according to O'Donnell et al. (2007).

Creole bean seeds, disinfested as previously described, were inoculated with $1 \mathrm{~mL}^{-1}$ of macroconidia suspension, at the final concentration of $8.0 \times 10^{5}$ macroconidia $\mathrm{mL}^{-1}$, obtained by counts in Neubauer's chamber, according to methodology adapted from Ellis et al. (2012). Seeds of both varieties, corresponding to the control treatment, received only $1 \mathrm{~mL}^{-1}$ of distilled and sterilized water. After inoculation of seeds, the following tests were conducted:

For the germination test, 200 seeds with inoculation of the pathogen and 200 seeds without inoculation were used for each variety of creole beans. Each treatment was divided into four replicates of 50 seeds, seeded in filter paper moistened with distilled water in the proportion of 2.5 times the dry mass of paper, according to a methodology adapted from Brasil (2009). Then, rolls were prepared, containing the seeds, which were arranged in a germination chamber at $25 \pm 2{ }^{\circ} \mathrm{C}$ and 12-hour photoperiod. Two counts were performed, the first at 5 and the second at 9 days (BRASIL, 2009). Normal (germination, \%) and abnormal (\%) seedlings were counted, as well as dead (DS, \%) and hard (HS, \%) seeds.

For the disease severity index and damping off quantification in each variety, 8 replicates with 25 seeds per treatment were used, seeded on germinating paper and moistened with 2.5 times the dry weight of the paper. After sowing, rolls were prepared and stored in black plastic bags and placed in a germination chamber at $25 \pm 2{ }^{\circ} \mathrm{C}$ and 12-hours photoperiod (ELLIS et al., 2012). After 7 days, roots and lesions were measured using a millimeter ruler $(\mathrm{mm})$ to obtain the disease severity index (DSI), with: DSI (\%) = length of lesion / length of seedlings x 100 (ELLIS et al., 2012). The occurrence of damping off in each treatment was quantified in percentage (\%) of symptomatic seedlings for treatment. 
The Germination Speed Index (GSI) was undertaken following the methodology adapted from Krzyzanowski et al. (1999), where the evaluation of germinated seeds was done daily with the normal seedling count up to the fifth day (BRASIL, 2009). After obtaining the daily data of the number of normal seedlings, the GSI was calculated through the Maguire (1962).

For the Emergency Speed Index (ESI) in each treatment 200 seeds were used, distributed in four replicates. The seeds were sown in to $5 \mathrm{~L}$ plastic trays, containing sterilized sand, autoclaved twice at $120^{\circ} \mathrm{C}$ and $1 \mathrm{~atm}$ for 1 hour, with a 24 hours interval between autoclaving. The evaluation of emerged seedlings was done daily until population stabilized, that is, when after two days no emergence of seedlings was observed. After obtaining the data, the ESI was calculated through the equation proposed by Maguire (1962).

Data were submitted to analysis of variance by the F-test $(\mathrm{p} \leq 0.05)$ and when significant, averages were compared by the Tukey test $(\mathrm{p} \leq 0.05)$. Except the data corresponding to ESI and GSI, all the others were transformed into arcsine $\sqrt{ } \mathrm{x} / 100$. The analysis was performed using the SISVAR (version 5.3) statistical software (FERREIRA, 2011).

\section{RESULTS AND DISCUSSION}

The 'Cavalo' variety had a higher percentage of germination $(\mathrm{G} \%)$ in the treatment without inoculation (73.6\%), while the inoculated seeds presented germination of $42.6 \%$ (Table 1). These results resemble those obtained by Broders et al. (2007) in which all the isolates of $F$. graminearum evaluated reduced germination of soybean and corn seeds compared to the control treatment.

Fusarium graminearum prejudice the germination of wheat seeds and other winter grains (CALORI-DOMINGUES et al., 2007). In addition, $F$. sporotrichioides Sherb., $F$. pseudograminearum (O'Donnell \& Aoki), F. verticillioides (Sacc.) Nirenberg, F. equiseti (Corda) Sacc. and F. semitectum Berk. \& Ravenel, have negatively affected the germination of soybean seeds, also causing damage to seedlings, although they are not considered true pathogens for the early stages of this culture (IVIC, 2014).

In relation to the 'Chumbinho' variety, there was a statistical difference between T1 - control (42.0\%) and T2 - inoculation (48.6\%) (Table 1). The higher germination in T2 for this variety could be explained by the fact that seed colonization by the pathogen has stimulated the synthesis of phytohormones, such as ethylene, in response to infection. This phytohormone can stimulate germination and act to overcome dormancy in seeds of several botanical species (NASCIMENTO, 
2003). The increase of endogenous ethylene was observed by Coleman \& Hodges (1987) in leaves of Poa pratensis L. in response to infection by Bipolaris sorokiniana (Sacc.) Shoemaker.

Table 1. Germination (G\%), abnormal seedlings (AS\%), death seeds (DS\%), hard seeds (HS\%), germination speed index (GSI), and emergency speed index (ESI) for creole bean seeds, 'Cavalo' and 'Chumbinho' varieties, with and without inoculation of macroconidia suspension of Fusarium graminearum $(F g)$. Erechim - RS, Brazil, 2015.

\begin{tabular}{|c|c|c|c|c|}
\hline \multirow{2}{*}{ Variable } & \multirow{2}{*}{ Treatments ${ }^{1}$} & \multicolumn{2}{|c|}{ Varieties } & \multirow{2}{*}{ C.V. (\%) } \\
\hline & & 'Cavalo' & 'Chumbinho' & \\
\hline \multirow{2}{*}{$\mathrm{G} \%$} & Control & $73.6 \mathrm{aA}^{2}$ & $42.0 \mathrm{bB}$ & \multirow{2}{*}{4.0} \\
\hline & $F g$ & $42.6 \mathrm{bA}$ & $48.6 \mathrm{aA}$ & \\
\hline \multirow{2}{*}{$\mathrm{AS} \%$} & Control & $17.5 \mathrm{bA}$ & $19.0 \mathrm{aA}$ & \multirow{2}{*}{3.2} \\
\hline & $F g$ & $27.0 \mathrm{aA}$ & $14.5 \mathrm{bB}$ & \\
\hline \multirow{2}{*}{$\mathrm{DS} \%$} & Control & $12.6 \mathrm{bB}$ & $47.5 \mathrm{aA}$ & \multirow{2}{*}{3.1} \\
\hline & $F g$ & $23.6 \mathrm{aB}$ & $45.3 \mathrm{aA}$ & \\
\hline \multirow{2}{*}{$\mathrm{HS} \%$} & Control & $12.0 \mathrm{aA}$ & $2.0 \mathrm{aB}$ & \multirow{2}{*}{7.4} \\
\hline & $\mathrm{Fg}$ & $10.0 \mathrm{bA}$ & $2.3 \mathrm{aB}$ & \\
\hline \multirow{2}{*}{$\mathrm{GSI}^{3}$} & Control & $8.1 \mathrm{aA}$ & $4.3 \mathrm{aB}$ & \multirow{2}{*}{6.5} \\
\hline & $\mathrm{Fg}$ & $6.8 \mathrm{bA}$ & $4.1 \mathrm{aB}$ & \\
\hline \multirow{2}{*}{$\mathrm{ESI}^{3}$} & Control & $3.1 \mathrm{aA}$ & $1.0 \mathrm{aB}$ & \multirow{2}{*}{16.5} \\
\hline & $F g$ & $2.3 \mathrm{bA}$ & $0.8 \mathrm{aB}$ & \\
\hline
\end{tabular}

${ }^{1}$ Treatments: T1) Control: seeds without inoculation of Fusarium graminearum; T2) Fg: seeds with inoculation of macroconidia suspension of Fusarium graminearum $\left(8 \times 10^{5}\right.$ macroconidia $\left.\mathrm{mL}^{-1}\right) .{ }^{2}$ Means followed by the same lower case letter in the column, and capital letter in the row not differ statistically from each other by the Tukey test $(\mathrm{p} \leq$ 0.05). ${ }^{3}$ Untransformed data.

The low germination percentage of the seeds of the 'Chumbinho' variety in both treatments could be associated with two things: the growing conditions at the farm and the subsequent storage of seed after harvest. In the first case, the loss of vigor and deterioration of seedlings can be related to how the farmer manages the crop and its cultural environment (MICHELS et al., 2014). In this situation, due to the seed drying process occurred on the plant, the seeds were under direct influence of the climatic conditions. After threshing, the seeds were packed in polypropylene bags (raffia). These conditions are less than optimum for seed storage and hence could have led to a decrease in seed quality. 
The seeds used in this trial had low germination, vigor, and low crop development (MICHELS et al., 2014). Generally, seed lines maintained by farmers remain uncertified for storage and germination effectiveness, which may reflect in their physiological quality.

In the 'Chumbinho' variety there was a higher percentage of abnormal seedlings (AS) in T1 (19.0\%), whereas in the 'Cavalo' variety, this variable was higher in T2 (27.0\%), when compared to $\mathrm{T} 1(17.5 \%)$, demonstrating the pathogenicity of $F$. graminearum on the normal formation of bean seedlings in this variety. For the control (T1), no statistical difference was observed between the varieties (Table 1). Menezes et al. (2011) observed that cucumber seeds inoculated with Fusarium spp. presented a higher percentage of abnormal seedlings in relation to the control.

Also for the 'Chumbinho' variety, inoculation of the pathogen did not influence the occurrence of dead seeds (DS) and hard seeds (HS) (Table 1). However, in the 'Cavalo' variety, a higher percentage of hard seeds was present in both treatments, differing statistically from the 'Chumbinho' variety. Additionally, in the 'Cavalo' variety, a higher percentage of DS in T2 (23.6\%) was also observed in relation to the control $(12.6 \%)$.

For the germination speed index (GSI) assessment, the 'Cavalo' variety expressed better results in both treatments, differing statistically from 'Chumbinho'. However, a higher GSI in T1 was observed for the 'Cavalo' variety (8.1), while in the 'Chumbinho' variety there was no statistical difference between the treatments.

The damage that the pathogenic microorganisms cause in the seeds at germination included damping off at pre and post-emergence, root rot and infections that affect the aerial part of the plants which reflects the quality of the seeds. With this, a reduction of germination, vigor and, even, the decay of the seeds can occur (FLÁVIO et al., 2014).

For the rate of emergence (ESI), the 'Cavalo' variety presented superior results compared to 'Chumbinho' in both treatments. However, in the 'Chumbinho' variety there was no statistical difference between T1 and T2. This is contrary to that observed by Menezes et al. (2011) in cucumber seeds, cv. 'Caipira', inoculated with Fusarium spp., in which there was reduction of the ESI in relation to non-inoculated seeds. For the 'Cavalo' variety, T2 showed a decrease in ESI, from 3.1 to 2.3 , in relation to T1 (Table 1).

The lower percentage of germination and GSI in the 'Chumbinho' variety, compared to the 'Cavalo', could be associated with the physiological and sanitary quality of the seeds, indicating a greater degree of degradation. According to Goulart (2005), the concept of vigor is important 
because it is an indicator parameter of seeds future performance in the field and the main factor that will influence good productivity.

For the disease severity index (DSI\%), in relation to normal (NS) and abnormal (AS) seedlings, for both treatments, the 'Chumbinho' variety had a higher incidence of lesions compared to the 'Cavalo' variety, where in T2 the DSI\% in normal seedlings was $20.9 \%$ and $38.8 \%$ in abnormal seedlings. For the 'Cavalo' variety, there was an increase in DSI\% with inoculation of F. graminearum, from $5.7 \%$ to $12.1 \%$ in NS and from $5.0 \%$ to $18.0 \%$ in AS (Table 2). Bellettini et al. (2005) evaluated the pathogenicity of fungi associated with peanut seeds, 'Tatu' cultivar, and verified that $35 \%$ of seedlings inoculated with Fusarium oxysporum Schlecht. presented lesions in the collar and roots region.

Table 2. Disease severity index (DSI\%) for normal and abnormal seedlings and incidence of damping off (\%) in creole bean seedlings, 'Cavalo' and 'Chumbinho' varieties, with and without inoculation of macroconidia suspension of Fusarium graminearum $(\mathrm{Fg})$. Erechim - RS, Brazil, 2015.

\begin{tabular}{|c|c|c|c|c|}
\hline \multirow{2}{*}{ Variable } & \multirow{2}{*}{ Treatments ${ }^{1}$} & \multicolumn{2}{|c|}{ Varieties } & \multirow{2}{*}{$\begin{array}{l}\text { C.V. } \\
(\%)\end{array}$} \\
\hline & & 'Cavalo' & 'Chumbinho' & \\
\hline \multirow{2}{*}{ DSI (\%) Normal seedlings } & Control & $5.7 \mathrm{bB}^{2,3}$ & $13.8 \mathrm{bA}$ & \multirow{2}{*}{9.2} \\
\hline & $F g$ & $12.1 \mathrm{aB}$ & $20.9 \mathrm{aA}$ & \\
\hline \multirow{2}{*}{ DSI (\%) Abnormal seedlings } & Control & $5.0 \mathrm{bB}$ & $21.5 \mathrm{bA}$ & \multirow{2}{*}{15.1} \\
\hline & $F g$ & $18.0 \mathrm{aB}$ & $38.8 \mathrm{aA}$ & \\
\hline \multirow{2}{*}{ Damping off $(\%)$} & Control & $0.0 \mathrm{bA}$ & $0.0 \mathrm{bA}$ & \multirow{2}{*}{19.1} \\
\hline & $F g$ & $19.6 \mathrm{aA}$ & $5.2 \mathrm{aB}$ & \\
\hline
\end{tabular}

${ }^{1}$ Treatments: T1) Control: seeds without inoculation of Fusarium graminearum; T2) Fg: seeds with inoculation of macroconidia suspension of Fusarium graminearum $\left(8 \times 10^{5}\right.$ macroconidia $\left.\mathrm{mL}^{-1}\right){ }^{2}$ arcsine $\sqrt{\mathrm{x}} / 100$ transformation. ${ }^{3}$ Means followed by the same lower case letter in the column, and capital letter in the row do not differ statistically from each other by the Tukey test $(\mathrm{p} \leq 0.05)$.

In a study by Broders et al. (2007), 105 isolates of $F$. graminearum were pathogenic to soybean and corn seeds. In greenhouse trials, F. graminearum infected germinated soybean and corn seedlings due to infested substrates, causing the appearance of necrotic lesions in seeds and soybean roots.

The transmission of $F$. graminearum from seeds to the bean seedlings was confirmed, with a higher incidence of damping off in the seedlings whose seeds were inoculated with the suspension 
of $F$. graminearum macroconidia (T2). In the 'Cavalo' variety, $19.6 \%$ of the seedlings presented symptoms of the disease and, therefore, this variety was more susceptible than 'Chumbinho', which presented 5.2\% damping off in $\mathrm{T} 2$ (Table 2).

$F$. graminearum has been identified as the etiological agent of wilt in soybean cultivars in Argentina (PIOLI et al., 2004) and in Croatia (DUVNJAK et al., 2016). Castillo et al. (2004) observed that $F$. semitectum and $F$. graminearum are the most frequent diseases to occur in black beans, in regions of Argentina that produce this grain. However, it should be noted that in Brazil, studies dealing with transmission and pathogenicity of $F$. graminearum in seeds of creole bean varieties are scarce.

The cultural residues of wheat and other winter cereals are an important source of $F$. graminearum inoculum for successive crops, such as bean, implying specialization of the pathogen on parasitism in a previously non-host species (SCHAAFSMA et al., 2005). Although less affected, the 'Chumbinho' variety was not immune to the occurrence of damping off, complementing the results obtained by Ellis et al. (2012) who, when testing the resistance of soybean cultivars to $F$. graminearum, observed that none of the genotypes evaluated in the study showed any resistance, and in all cases, there was development of lesions. These results also corroborate those obtained by Peruzzo et al. (2015), in which the infection of soybean cultivars by $F$. graminearum, in greenhouse, reduced the physiological quality of the seeds. However, in our study, we noted that, in the control treatment, the incidence of damping off for both bean varieties was not verified. With this, it is possible to infer that Fusarium graminearum can cause damages in the bean establishment, compromising the vigor of the seeds, mainly in the 'Cavalo' variety.

\section{CONCLUSION}

Considering the changes in vigor and incidence of damping off in both varieties of creole bean, 'Cavalo' and 'Chumbinho' evaluated in this study, the pathogenicity of $F$. graminearum has been demonstrated. The variety 'Cavalo' is more susceptible to $F$. graminearum, expressing vigor reduction, incidence of root lesions and damping off. 


\section{REFERENCES}

BElletTini, N. M. T.; ENDO, R. M.; MigliORANZA, E.; SANTIAGO, D. C. 2005. Patogenicidade de fungos associados às sementes e plântulas de amendoim cv. Tatu. Semina: Ciências Agrárias, Londrina, v. 26, n. 2, p. 167-172.

BILGI, V. N.; BRADLEY, C. A.; MATHEW, F. M.; ALI, S.; RASMUSSEN, J. B. 2011. Root Rot of Dry Edible Bean Caused by Fusarium graminearum. Plant Health Progress, Saint Paul, V. 12, n. 1.

BRASIL. 2009. Ministério da Agricultura, Pecuária e Abastecimento. Regras para Análise de Sementes. Secretaria de Defesa Agropecuária. Brasília, DF: Mapa/ACS, 395p.

BRODERS, K. D.; LIPPS, P. E.; PAUL, P. A.; DORRANCE, A. E. 2007. Evaluation of Fusarium graminearum Associated with Corn and Soybean Seed and Seedling Disease in Ohio. Plant Disease, Saint Paul, v. 91, n. 9, p. 1155-1160.

CALORI-DOMINGUES, M. A.; ALMEIDA, R. R.; TOMIWAKA, M. M.; GALlO, C. R.; GLORIA, E. M.; DIAS, C. T. S. 2007. Ocorrência de desoxinivalenol em trigo nacional e importado utilizado no Brasil. Revista Ciência e Tecnologia de Alimentos, Campinas, v. 27, p. 181-185.

CASTILlO, M. D.; GONZÁlEZ, H. H. L.; MARTíNEZ, E. J.; PACIN, A. M.; RESNIK, S. L. 2004. Mycoflora and Potential for Mycotoxin Production of Freshly Harvested Black Bean from the Argentinean Main Production Area. Mycopathologia, Netherlands, v. 158, p. 107112.

COLEMAN, L. W.; HODGES, F. 1987. Ethylene Biosynthesis in Poa pratensis Leaves in Response to Injury or Infection by Bipolaris sorokiniana. Phytopathology, Saint Paul, v.77, n. 9, p. 1280-1283.

DIDONET, A. D. 2013. Produção informal de semente de feijão comum com qualidade. Brasília, DF: Embrapa. 35p.

DUVNJAK, T.; SUDARIĆ, A.; KOČAR, M. M.; ĆOSIĆ, J.; VRANDEČIĆ, K. 2016. First report of soybean Fusarium wilt caused by Fusarium graminearum in Croatia. Plant Disease, Saint Paul, v. 100, n. 3, p. 648.

ELLIS, M. L.; BRODERS, K. D.; PAUL, P. A.; DORRANCE, A. E. 2011. Infection of soybean seed by Fusarium graminearum and effect of seed treatments on disease under controlled conditions. Plant Disease, Saint Paul, v. 95, n. 4, p. 401-407.

ELLIS, M. L.; WANG, H.; PAUL, P. A.; ST. MARTIN, S. K.; MCHALE, L. K.; DORRANCE, A. E. 2012. Identification of soybean genotypes resistant to Fusarium graminearum and genetic mapping of resistance quantitative trait loci in the cultivar Conrad. Crop Science, Madison, v. 52, n. 5, p. 2224-2233.

FERREIRA, D. F. 2011. Sisvar: a computer statistical analysis system. Ciência e Agrotecnologia, Lavras, v. 35, n.6, p. 1039-1042.

FLÁVIO, N. S. D. DA S.; SALES, N. DE L.P.; AQUINO, C. F.; SOARES, E. P. S.; AQUINO, L. F. S.; CATÃO, H. C. R. M. 2014. Qualidade sanitária e fisiológica de sementes de sorgo tratadas com extratos aquosos e óleos essenciais. Semina: Ciências Agrárias, Londrina, v. 35, n. 1, p. 7-20.

GOUlART, A. C. P. 2005. Fungos em Sementes de Soja: detecção, importância e controle. Dourados: Embrapa Agropecuária Oeste. 72p.

GLASS, N.L.; DONALDSON, G.C. 1995. Development of primer sets designed for use with the PCR to amplify conserved genes from filamentous ascomycetes. Applied and Environmental Microbiology, Washington DC, v. 61, n. 4, p. 1323-1330. 
IVIC, D. 2014. Pathogenicity and potential toxigenicity of seed-borne Fusarium species on soybean and pea. Journal of Plant Pathology, Torino, n. 96, v. 3, p. 541-551.

KRZYZANOWSKI, F. C.; VIEIRA, R. D.; FRANÇA-NETO, J. B. 1999. Vigor de Sementes: Conceitos e Testes. Londrina: ABRATES, 214 p.

LESLIE, J. F.; SUMMERELL, B. A. 2006. The Fusarium Laboratory Manual. Ames: Blackwell Publishing, $388 \mathrm{p}$.

MAGUIRE, J. D. 1962. Speed of germination-aid selection and evaluation for seedling emergence and vigor. Crop Science, Madison, v. 2, p. 176-177.

MENEZES, V. O.; PEDROSO, D. C.; PIVETA, G.; MUNIZ, M. F. B.; MENEZES, N. L.; GARCIA, D. C.; ETHUR, L. Z.; SANTOS, R. F.; TUNES, L. M. 2011. Detecção e influência de Fusarium spp. na qualidade fisiológica de sementes de pepino. Ciência Rural, Santa Maria, v. 41, n. 2, p. 193-199.

MICHELS, A. F.; SOUZA, C. A.; COELHO, C. M. M.; ZILIO, M. 2014. Qualidade fisiológica de sementes de feijão crioulo produzidas no oeste e planalto catarinense. Revista Ciência Agronômica, Fortaleza, v. 45, n. 3, p. 620-632.

NASCIMENTO, W. M. 2003. Ethylene and lettuce seed germination. Scientia Agricola, Piracicaba, v. 60, n. 3, p. 601-606.

NELSON, P.E.; TOUSSON, T.A.; MARASAS, W.F.O. 1983. Fusarium species: an illustrated manual for identification. Philadelphia: Pennsylvania State University Press. 192p.

O'DONNELL, K.; SARVER, B. A.J.; BRANDT, M.; CHANG, D. C.; NOBLE-WANG, J.; PARK B. J.; SUTTON, D. A.; BENJAMIN L.; LINDSLEY, M.; PADHYE, A.; GEISER, D. M.; WARD, T. J. 2007. Phylogenetic diversity and microsphere array-based genotyping of human pathogenic Fusaria, including isolates from the multistate contact lens-associated U.S. keratitis outbreaks of 2005 and 2006. Journal of Clinical Microbiology, Washington DC, v. 45, n. 7, p. 2235-2248.

PERUZZO, A. M.; PIOLI, R. N.; SALINAS, A. R. 2015. Effect of Fusarium graminearum Schwabe on physiological quality of soybean seeds and wheat caryopsis in Argentina. Revista Caatinga, Mossoró, v. 28, n. 3, p. 1-11.

PIOLI, R. N.; MOZZONI, L.; MORANDI, E.N. 2004. First report of pathogenic association between Fusarium graminearum and soybean. Plant Disease, Saint Paul, v. 88, n. 2, p. 220.

REIS, E.M.; SEGALIN, M.; MORAES, N.L.; GHISSI, V.C. 2014. Efeitos da rotação de culturas na incidência de podridões radiciais e na produtividade da soja. Summa Phytopathologica, Botucatu, v. 40, n. 1, p. 09-15.

SCHAAFSMA, A.W.; TAMBURIC-ILINCIC, L.; HOOKER, D.C. 2005. Effect of previous crop, tillage, field size, adjacent crop, and sampling direction on airborne propagules of Gibberella zeae/Fusarium graminearum, fusarium head blight severity, and deoxynivalenol accumulation in winter wheat. Canadian Journal of Plant Pathology, Ottawa, v. 27, n. 2, p. 217-224.

TSUTSUMI, C. Y.; WAGATSUMA, É.; NORETO, L. M.; MATTIELLO, V. D.; KLEIN, J. 2012. Cultivares de feijão produzidos em sistema de cultivo orgânico. Cultivando o Saber, Cascavel, v. 5, n. 3, p. 123-131. 